\title{
Properti Psikometrik dan Struktur Skala Kemalasan Sosial (Social Loafing) pada Mahasiswa
}

\author{
Ivan Muhammad Agung, Rita Susanti, Rawdhatul Fitri Yunis
}

\author{
Fakultas Psikologi Universitas Islam Negeri Sultan Syarif Kasim Riau \\ email:ivan.agung@uin-suska.ac.id
}

\begin{abstract}
Abstrak
Artikel INFO

Diterima:16 Juli 2019

Direvisi : 27 Nov 2019

Disetujui: 5 Des 2019

DOI:

http://dx.doi.org/10.24014/ jp.v14i2.7413

Kemalasan sosial merupakan salah satu tema yang banyak dibahas dalam konteks Psikologi kelompok. Kemalasan sosial berperan penting dalam menentukan kualitas kinerja kelompok. Penelitian ini bertujuan untuk menemukan struktur skala kemalasan sosial dan menguji reliabilitas pengukuran. Alat ukur yang digunakan skala kemalasan sosial yang dimodifikasi dari skala George, (1992). Penelitian dilakukan pada 210 mahasiswa. Hasil penelitian dengan analisisi faktor eksplaratori terbentuk 4 komponen, yaitu persepsi atas usaha, mengurangi usaha, membiarkan orang lain melakukan lebih dan mengandalkan orang lain.Secara umum skala ini memiliki reliabitas (alpha) yang baik secara psikometrik. Hasil dan implikasi penelitian akan dibahas dalam artikel ini.
\end{abstract}

Kata kunci: kemalasan sosial, analisis faktor, mahasiswa

\section{Psychometric Properties and Structure of Social Loafing Scale on Undergraduate Student}

\begin{abstract}
Social loafing is one of the themes that is widely discussed in the context of group psychology. Social loafing plays an important role in determining the quality of group performance. This study aims to find the scale structure of social loafing and test the reliability of measurements. The measuring instrument used was a scale of social loafing scale modified from the George, (1992). The study was conducted on 210 students. The results of the study with an exploratory factor analysis formed 4 components, namely perception of effort, reducing effort, letting others do more and relying on others. In general, this scale has a good psychometric reliability (alpha). The results and implications of the study will be discussed in this article
\end{abstract}

Keywords: social loafing, factor analysis, undergraduate student

\section{Pendahuluan}

Bekerja dalam kelompok menjadi bagian penting dalam kehidupan manusia. Bekerja dalam kelompok dapat mempercepat dan mempermudah dalam penyelesaian tugas, serta meningkatkan kualitas kerja kelompok. Namun demikian bekerja dalam kelompok tidak semua dapat berjalan dengan baik, terkadang ada dapat menimbulkan konflik atau perselisihan karena ketidakjelasan tugas atau kotribusinya yang tidak seimbang pada anggota kelompok. Individu mengerjakan tugas tidak maksimal atau mengurangi usaha ketika bekerja dalam kelompok dibanding bekerja sendiri biasa disebut dengan kemalasan sosial (social loafing) (George, 1992; Karau, \& Williams, 1993)

Kemalasan sosial merupakan salah satu isu penting yang banyak dibahas dalam penelitian psikologi kelompok. Kemalasan sosial berimplikasi pada kinerja kelompok. Chidambaram dan Tung (2005) menyebutkan bahwa kemalasan sosial merupakan sebuah fenomena yang merugikan bagi kelompok karena mengurangi performa atau kinerja dalam melaksanakan tugas dan menghalangi kesejahteraan kelompok (Jassawalla, Sashittal, \& Malshe, 2009). Penelitian Mulvey, dan Klein, (1998) menunjukkan bahwa kemalasan sosial mempengaruhi proses kelompok (tujuan dan komitmen) dan kinerja kelompok. Dalam konteks pembelajaran, kemalasan sosial dapat terjadi pada pengerjaan tugas kelompok. ketika seseorang melakukan kemalasan sosial sebenarnya ia menghambat dirinya sendiri dalam mencapai sasaran-sasaran pembelajaran yang seharusnya ia pelajari dan kontribusikan selama proses pengerjaan tugas kelompok (Zahra, dkk, 2015). 
Kemalasan sosial merupakan suatu kondisi ketika kontribusi individu pada aktivitas kolektif tidak dapat dievaluasi, individu sering bekerja kurang giat dalam kelompok dibandingkan saat bekerja sendirian (Taylor, Peplau \& Sears,, 2009). Kemalasan sosial merupakan pengurangan motivasi dan usaha ketika individu bekerja secara kolektif dalam kelompok dibandingkan bila mereka bekerja sendiri (Baron \& Byrne, 2005). George (1992) yang menyebutkan bahwa kemalasan sosial merupakan kondisi dimana individu hanya melakukan sedikit usaha untuk menyelesaikan tugas kelompok saat ada anggota kelompok yang lain melakukan tugas tersebut. Latane, William dan Harkins (1979) mengatakan bahwa kemalasan sosial mengarah pada pengurangan usaha individu ketika bekerja dalam kelompok namun tidak terjadi pengurangan usaha ketika individu tersebut bekerja seorang diri.

Kemalasan sosial terjadi disebabkan banyak faktor baik intrinsik maupun ekstrinsik (George, 1992; Harmaini, dkk 2016). Pertama, faktor ektrinsik, yang meliputi karakter tugas yang mudah diamati. Ketika individu mengerjakan tugas yang dapat dengan jelas dinilai oleh orang lain, maka kemalasan sosial akan rendah. Jumlah kelompok dan rendahnya kohesivitas juga dapat berperan dalam terjadinya kemalasan sosial. Semakin banyak jumlah anggota kelompok, maka perluang terjadinya kemalasan sosial lebih tinggi (Liden., dkk 2004).Selain itu, pembagian tugas dan evaluasi tugas tidak jelas akan berpotensi meningkatkan kemalasan sosial (Bordens \& Horowitz, 2008). Kedua, faktor instrinsik, yaitu sejauh mana individu merasa bermakna, berharga dan penting atas kontribusi yang diberikan kepada kelompok. Ketika indvidu merasa kontribusinya unik dan memiliki arti penting bagi kelompok, maka kemalasan sosial cenderung berkurang (Harkin \& Petty, 1982)

Penelitian kemalasan sosial sudah banyak dilakukan dengan beberapa variabel penelitian, seperti, faktor ekstrinsik (kejelasan dan kesulitan tugas) dan faktor intrinsik (George, 1992; Harkin \& Petty, 1982); kohesi kelompok dan norma kelompok (Hoigaard, Safvenbom, \& Tønnessen 2006); persepsi keadilan dan relasi (Murphy, dkk 2003); evaluasi kelompok (Harkins, \& Szymanski, 1989), kepribadian dan budaya (Klehe \& Anderson, 2007); visibiltas tugas, keadilan distributif, dan persepsi anggota (Liden., dkk 2004); proses kelompok dan kolektif self efikasi (Mulvey, \& Klein, (1998).Sementara di Indonesia penelitian tentang kemalasan sosial dikaitkan dengan kohesivitas (Anggraeni \& Alfian 2015; Krisnasari \& Purnomo, 2017); pro sosial (Setyawan, dkk 2016); persepsi dukungan organisasi, komitmen organisasi dan kepuasan kerja (Saputra, dkk, 2016); self esteem (Kusuma, 2015); motivasi berprestasi (Metiasie, 2016); persahabatan (Audi, 2014).

Konsep kemalasan sosial merupakan konsep yang tidak mudah untuk diukur. Pengukuran kemalasan sosial membutuhkan konteks kelompok, sehingga beberapa penelitian menggunakan metode ekperimen dalam menghadiri suasana atau situasi kelompok (Harkin \& Petty, 1982; Hoigaard, Safvenbom, \& Tønnessen, 2006; Williams, \& Karau, 1991)) dan metode non eksperimen (George, 1992; Krisnasari \& Purnomo, 2017). Selain itu, pengukuran kemalasan sosial dapat ditujukan ke dalam (diri sendiri), yaitu mengukur diri sendiri dan keluar (orang lain), yaitu persepsi kemalasan sosial yang dilakukan orang lain.Beberapa penelitian, menggunakan konsep berbeda dalam mengukur kemalasan sosial, salah satu skala kemalasan sosial yang banyak digunakan adalah dari penelitian George (1992). Beberapa penelitian menggunakan skala kemalasan sosial dari George (1992), seperti Murphy, dkk (2003); Liden, dkk., (2004). Pada penelitian akan menggunakan pengukuran kemalasan sosial berdasarkan pengukuran George (1992) yang dimodifikasi dari sisi konteks dan jumlah aitem. Pada penelitian George (1992) konteksnya dunia kerja, sementara penelitian ini konteksnya akademik, yaitu pengerjaan tugas kelompok di kampus. Selain itu, jumlah 10 aitem bertambah menjadi 24 aitem. Penelitian ini bertujuan untuk mengeksplorasi struktur skala kemalasan sosial pada mahasiswa, selain itu penelitian juga menguji reliabilitas dengan alpha Cronbach.

\section{Metode}

\section{Partisipan}

Partisipan merupakan mahasiswa yang terlibat dalam tugas kelompok yaitu mahasiswa Fakultas Psikologi UIN Suska Riau kota Pekanbaru semester II, IV dan VI berjumlah 210 mahasiswa (173 wanita dan 37 pria). 


\section{Pengukuran}

Skala Kemalasan sosial dibuat berdasarkan skala kemalasan sosial dari George (1992) yang dilakukan modifikasi dengan cara penambahan aitem, sebanyak 14 aitem sehingga. Total aitem sebanyak 24 aitem. Model Skala Likert dengan lima alternatif jawaban, yaitu Sangat Setuju (SS), Setuju (S), Kurang Setuju (KS), Tidak Setuju (TS) Sangat Tidak Setuju (STS) dengan rentang penilaian 1 sampai 5 . Uji coba skala penelitian (try out) dilakukan dengan membagikan Skala Kemalasan sosial kepada 60 mahasiswa. Berdasarkan hasil analisis terhadap 24 aitem skala kemalasan sosial yang telah diuji-cobakan, terdapat 3 aitem yang gugur dan 21 aitem yang valid dengan koefesien reliabilitas sebesar 0,942.

\section{Analisis data}

Analisis penelitian dilakukan dengan analsis faktor eksplatori dengan bantuan program SPSS analisis faktor eksplaratori yang bertujuan untuk mengidentifikasi faktor-faktor yang terbentuk dalam suatu pengukuran (Hair, dkk, 2006; Steven, 2009). Ekstraksi faktor dilakukan dengan metode principal component analysis (PCA). Menurut Fabrigar, dkk., (1999) PCA merupakan metode yang sesuai untuk mereduksi data.
Beberapa tahapan yang dilakukan dalam analisis factor eksplaratori, yaitu;input data, uji pendahuluan, ekstraksi factor dan rotasi, dan identifikasi komponen.

\section{Hasil}

Ada beberapa uji pendahuluan yang dilakukan yaitu Kaiser-Meyer-Olkin Measure of Sampling Adequacy (KMO) bertujuan untuk melihat apakah data atau sampel adekuat untuk dilakukan analisis factor. KMO bergerak dari 0 sampai 1 . selanjutnya uji Bartlet's tes bertujuan untuk menilai apakah suatu variabel berkorelasi signifikan dengan. variabel lain dengan kriteria $p<0,01$. Measures of sample of adecuacy (MSA) bertujuan untuk melihat korelasi antarvariabel/ aitem dalam data penelitian. Analisis faktor dapat dilakukan jika korelasi antarvariabel/ aitem lebih besar 0,5 (Hair, dkk, 2006). Hasil penelitian menunjukkan $\mathrm{KMO}=0,896, \mathrm{x}^{2}$ $(210)=1670.628, p=0,000$. Hal tersebut menunjukkan bahwa semua variabel dapat diikutkan dalam analisis lanjutan.

Setelah dilakukan analisis faktor dengan metode Principal Component Analysis (PCA) terbentuk 4 komponen. Penentuan ini berdasarkan pada nilai initial eigenvalues di atas 1(Hair, dkk., 2006). Keempat komponen (faktor) memiliki nilai kumulatif varians sebesar $55,12 \%$., artinya keempat komponen mampu menjelaskan $55,12 \%$ varians skala kemalasan sosial.

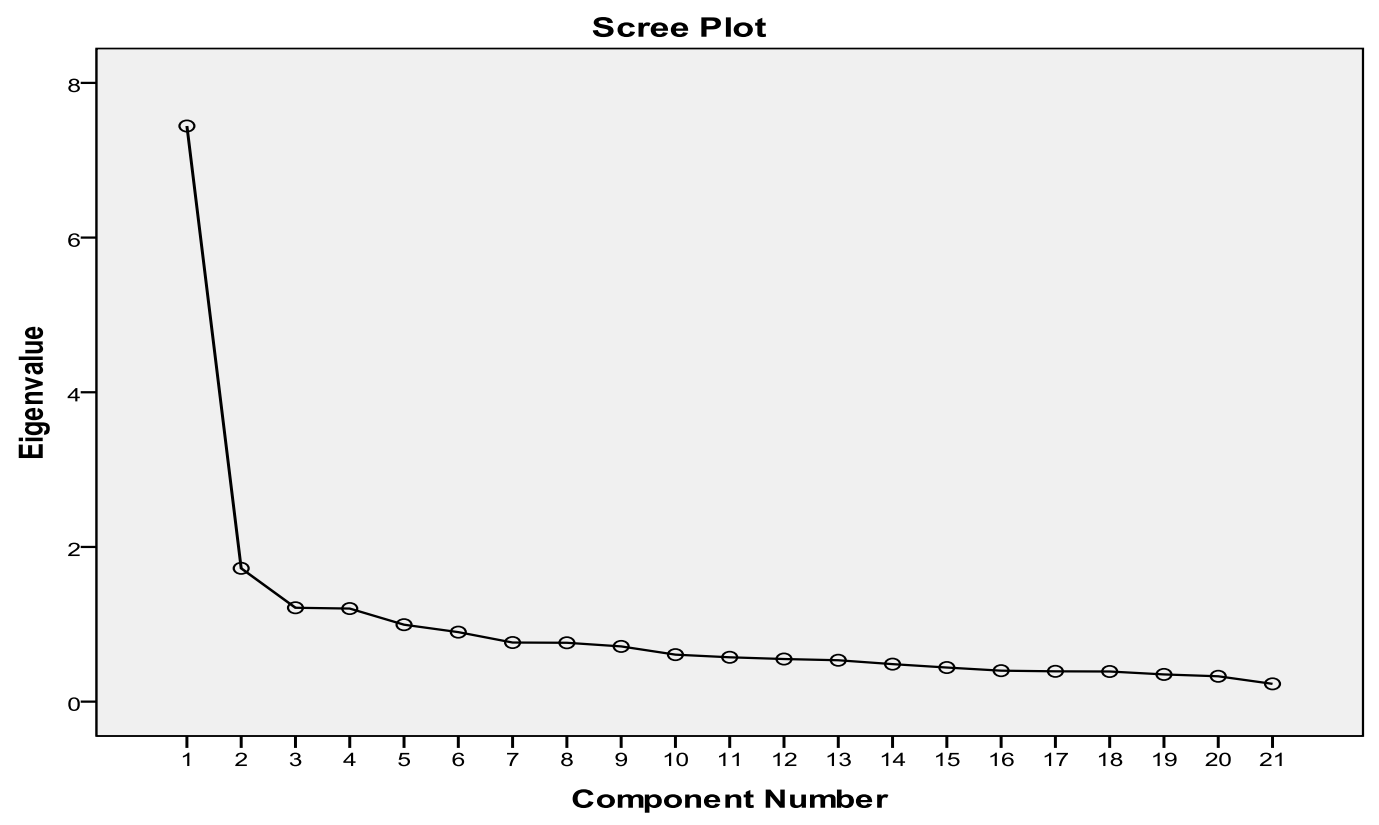

Gambar 1. Jumlah komponen skala kemalasan sosial 
Setelah dilakukan rotasi dengan terdiri dari 7 aitem, komponen 2: mengurangi metode varimax diperoleh penyebaran usaha(15.543\%)terdiridari5aitem, komponen aitem yang memiliki faktor loading pada 3 :membiarkan orang lain melakukan lebih, setiap komponen. Tahap selanjutnya (12,915\%) terdiri dari 3 aitem dan komponen adalah interpretasi komponen dengan cara 4 :mengandalkan orang lain (10,688\%) terdiri memberikan nama pada setiap komponen. dari 3 aitem sehingga total 18 aitem yang Komponen 1:persepsi atas usaha $(16,013 \%)$, valid dan 3 aitem gugur.

Tabel 1. Rotasi Faktor (Komponen) Skala Kemalasan Social (Social Loafing)

\begin{tabular}{|c|c|c|c|c|c|}
\hline \multirow{2}{*}{ No } & \multirow{2}{*}{ Variabel/aitem } & \multicolumn{4}{|c|}{ Komponen } \\
\hline & & 1 & 2 & 3 & 4 \\
\hline 1 & $\begin{array}{l}\text { Saya merasa bahwa kontribusi saya dalam kelompok } \\
\text { dapat diwakili oleh anggota kelompok yang lain yang bisa } \\
\text { menvelesaikan tugas kelompok }\end{array}$ & .758 & & & \\
\hline 2 & $\begin{array}{l}\text { Usaha anggota kelompok yang lain telah memenuhi usaha } \\
\text { saya dalam mengerjakan tugas kelompok }\end{array}$ & 679 & & & \\
\hline 3 & $\begin{array}{l}\text { Saya mengerjakan tugas sedikit saja karena ada teman } \\
\text { kelompok saya yang akan menyelesaikannya }\end{array}$ & .625 & & & \\
\hline 4 & $\begin{array}{l}\text { Saya merasa bahwa anggota yang lain telah memenuhi } \\
\text { tugas kelompok sehingga saya tidak perlu lagi ikut serta } \\
\text { mengerjakannya }\end{array}$ & .578 & & & \\
\hline 5 & $\begin{array}{l}\text { Saya menghindari mengerjakan tugas sebanyak mungkin; biar } \\
\text { saja anggota kelompok yang lain yang mengerjakan }\end{array}$ & .534 & & & \\
\hline 6 & $\begin{array}{l}\text { Saya berhenti mengerjakan tugas kelompok apabila ada } \\
\text { anggota lain yang akan menyelesaikan tugas kelompok }\end{array}$ & .503 & & & \\
\hline 7 & $\begin{array}{l}\text { Saya kurang memberikan kontribusi untuk tugas karena ada } \\
\text { teman kelompok yang menyelesaikannya }\end{array}$ & .500 & & & \\
\hline 8 & $\begin{array}{l}\text { Saya enggan melakukan usaha untuk menyelesaikan } \\
\text { tugas kelompok apabila ada anggota kelompok lain yang } \\
\text { menyelesaikannya }\end{array}$ & .463 & & .443 & \\
\hline 9 & $\begin{array}{l}\text { Saya mengurangi usaha saya apabila ada teman kelompok } \\
\text { yang mengerjakannya }\end{array}$ & & .769 & & \\
\hline 10 & $\begin{array}{l}\text { Saya mengerjakan tugas sekedarnya saja karena ada teman } \\
\text { kelompok saya yang akan menyelesaikannya }\end{array}$ & & .756 & & \\
\hline 11 & Saya menghindari mengerjakan tugas yang banyak & & .732 & & \\
\hline 12 & Teman saya yang lebih banyak mengerjakan tugas kelompok & & .710 & & \\
\hline 13 & $\begin{array}{l}\text { Saya memilih mengerjakan tugas yang mudah dan membiarkan } \\
\text { teman kelompok saya mengerjakan yang lebih sulit }\end{array}$ & & .582 & & \\
\hline 14 & $\begin{array}{l}\text { Saya membiarkan tugas bagian saya dikerjakan oleh anggota } \\
\text { kelompok yang lain }\end{array}$ & & & .712 & \\
\hline 15 & $\begin{array}{l}\text { Saya ingin teman kelompok saya saja yang menyelesaikan } \\
\text { tugas }\end{array}$ & & & .708 & \\
\hline 16 & Saya membiarkan teman saya mengerjakan tugas kelompok & & & 692 & \\
\hline 17 & $\begin{array}{l}\text { Terkadang saya menyerahkan tugas kelompok kepada teman } \\
\text { yang saya anggap bisa menyelesaikan tugas kelompok }\end{array}$ & & & & .714 \\
\hline 18 & $\begin{array}{l}\text { Terkadang saya mengandalkan teman kelompok saya untuk } \\
\text { menyelesaikan tugas kelompok }\end{array}$ & & & & .712 \\
\hline 19 & $\begin{array}{l}\text { Setelah merasa cukup berkontribusi, saya menyerahkan } \\
\text { penyelesaian tugas kepada anggota kelompok yang lain }\end{array}$ & & & & .488 \\
\hline 20 & $\begin{array}{l}\text { Saya memilih diam apabila teman kelompok saya bisa } \\
\text { menyelesaikan tugas kelompok }\end{array}$ & & & .457 & .486 \\
\hline 21 & Saya membiarkan teman bekerja lebih banyak daripada saya & & & & \\
\hline
\end{tabular}


Ket: $\mathrm{N}=210$, aitem yang digunakan memiliki faktor loading $>0,40$. Sementara ada 1 aitem (no 21) yang memiliki faktor loading $<0,4$ dan 2 aitem (no.8, 20) mengukur pada dua komponen yang sama, sehingga tidak diikutkan dalam penelitian.

Sementara uji reliabilitas dengan alpha menunjukkan komponen 1, 2, 3 memiliki reliabilitas yang baik secara psikometri $(0,82,082$, dan 0,71$)$ sementara komponen 4 memiliki reliabilitas sebesar 0.59 (kurang). Namun demikian secara keseluruhan uji reliiabilitas sebesar 0.89. Hal ini menunjukkan bahwa skala kemalasan sosial memiliki reliabilitas yang dapat diandalkan secara psikometrik.

\section{Pembahasan}

Penelitian ini bertujuan untuk mengeksploarasi struktur komponen skala kemalasan sosial pada mahasiswa, serta melakukan pengujian relibilitas terhadap skala tersebut. Hasil penelitian menunjukkan bahwa terdapat empat komponen pada skala kemalasan sosial, pertama, persepsi atas usaha, yaitu penilaian individu atas usaha sendiri dan anggota kelompok. Indvidu yang menilai usaha tidak berkontribusi signifikan terhadap kelompok dan menilai anggota kelompok lain mampu menyelesaikan tugasnya dengan baik, maka indvidu akan cenderung memiliki kemalasan sosial lebih tinggi. Selain itu persepsi terhadap temannya juga berperan dalam meunculkan perilaku kemalasan sosial. Hasil penelitian menunjukkan bahwa persepsi terhadap anggota kelompok dapat berperan dalam memunculkan kemalasan sosial. Indvidu yang mempersepsikan teman anggota kelompok memilki kemampuan baik cenderung mengalami kemalasan sosial (Mulvey, \& Klein, 1998; Williams, \& Karau, 1991).

Kedua, mengurangi usaha, yaitu indvidu cenderung mengurangi usaha atau tidak memberikan kontribusi maksimal terhadap pengerjaan tugas kelompok. Indvidu yang mengalami kemalasan sosial cenderung mengurangi usaha atau hanya mengerjakan tugas relatif sedikit dibandingkan temanya. pengurangan usaha dapat disebabkan oleh tidak dapat teramati kontribusi indvidu secara jelas (George, 1992; Latane, Williams, a\& Harkins 1979; Karau, \& Williams, 1993).).. Ketiga, membiarkan orang lain melakukan lebih, yaitu individu cenderung membiarkan anggota kelompok lain untuk mengambil peran lebih besar.Indvidu yang mengalami kemasalasan sosial cenderung membiarkan anggota kelompok lain untuk menyelesaikan tugas lebih banyak. Keempat, mengandalkan orang lain, yaitu individu yang mempersepsikan teman anggota dapat diandalkan dalam menyelesaikan tugas, maka individu cenderung megandalkan temannya dalam menyelesaikan tugas.

Hasil analisisi faktor pada skala kemalasan sosial terbentuk 4 komponen berdasarkan korelasi setiap aitem pada komponen yang terlihat dari faktor loading pada setiap aitem. Namun ketika dianilisis secara konten aitem, ada beberapa aitem antar komponen yang tidak konsisten, terutama komponen 1 dan komponen 2. Misalkan aitem no 5 "Saya menghindari mengerjakan tugas sebanyak mungkin, biar saja anggota kelompok yang lain yang mengerjakan" dan aitem 11 "Saya menghindari mengerjakan tugas yang banyak", aitem no 3" Saya mengerjakan tugas sedikit saja karena ada teman kelompok saya yang akan menyelesaikannya" dengan aitem no 10" "Saya mengerjakan tugas sekedarnya saja karena ada teman kelompok saya yang akan menyelesaikannya" . contoh aitem tersebut relatif sama secara isi, namun berada pada komponen yang berbeda.

Demikian juga pada komponen 3 (Membiarkan orang lain melakukan lebih dan komponen 4 (Mengandalkan orang lain) tidak secara jelas pemisahannya atau perbedaan pada setiap komponen, keduanya sama-sama menjelaskan anggota lain untuk bekerja lebih banyak dari dirinya. Apabila mengacu definisi awal kemalasan sosial adalahpengurangan usaha ketika bekerja kelompok dibandingkan bekerja sendiri (Karau, \& Williams, 1993), maka indikator utamanya adalah pengurangan usaha, dengan bentuk perilaku membiarkan orang lain melakukan usaha lebih dan mengandalkan orang lain. Sementara persepsi atas usaha merupakan anteseden dari kemalasan sosial. Oleh karena itu, perlunya definisi yang jelas dan tegas pada setiap komponen sehingga pembuatan aitemnya tidak overlap dengan komponen lain. Selain itu, perlu juga dipertimbangan apakah skala kemalasan sosial ini bersifat unidimensi atau multidimensi. Dilihat dari kontennya (aitem), skala kemalasan sosial lebih pada skala yang bersifat unidimensional, artinya skala mengukur satu kosntruk. Namun demikian, perlu pengujian lebih lanjut tentang hal ini.

Hasil penelitian ini berbeda dengan penelitian Jassawalla, Sashittal, \& Malshe, 
(2009) yang menunjukkan skala kemalasan sosial bersifat kompleks dan multidimensi. Hasil penelitianya menunjukkan bahwa perilaku kemalasan sosial ditunjukkan pada dua aspek, yaitu pengurangan usaha yang dikaitkan dengan rendahnya kualitas kerja dan perilaku distruptive dan distractive, seperti menganggu atau membuat kekacauan ketika bekerja kelompok. Hal itu dapat disebabkan cara konstruksi skala kemalasan sosialnya berbeda. Pada penelitian Jassawalla, Sashittal, \& Malshe, (2009) konstruksi skala kemalasan sosial diawali penelitian kualitatif dengan analisis konten dan dilanjutkan analisis kuantitatif. Namun demikian, secara isi, dan konsep relatif sama, yaitu kemalasan sosial adalah individu yang mengurangi usaha ketika bekerja dalam kelompok dan melakukan tindakan yang dapat merusak kinerja kelompok.

Keterbatasan penelitian diantaranya, jumlah dan karakteristik subjek terbatas, diperlukan jumlah dengan karakteristik subjek yang bragam agar mendapatkan hasil yang dapat digeneralisasikan. Akhirnya analisis faktor skala kemalasan sosial merupakan langkah awal untuk mengeskplorasi struktur skala kemalasan sosial.Masih perlukan perbaikan khususnya dalam penulisan aitem, serta menguji validitas konstrak pada penelitian selanjutnya dengan metode berbeda, sehingga memperoleh skala yang lebih sahih secara psikometrik.

\section{Kesimpulan}

Berdasarakan analisisi faktor menunjukkan bahwa terdapat empat komponen skala kemalasan sosial pada mahasiswa, yaitu persepsi atas usaha, mengurangi usaha, membiarkan orang lain melakukan lebih dan mengandalkan orang lain. Secara umum uji reliabilitas skala kemalasan sosial memiliki reliabilita yang dapat diandalkan secara psikometrik. Namun demikian perlu pertimbangan secara isi aitem dengan komponen, karena beberapa aitem secara isi tidak konsisten dengan komponen.

\section{Daftar Pustaka}

Audi, N.L.(2014). Persahabatan dan Toleransi Pemalasan Sosial Pada Mahasiswa Psikologi Universitas Sumatera Utara, Psikologia, 9(2), 52-56.

Baron, R. A. \& Byrne. D. (2005). Psikologi Sosial. Jilid II. Edisi Kesepuluh. Terj. Jakarta : Erlangga.
Bordens, K,S \& Horowitz, I,A. (2008). Social Psychology. 3rd Edition. Freeload press.

Chidambaram, T. \& Tung, L. L. (2005). Is out of sight, out of mind? An empirical study of social loafing in technology-supported groups. Information Systems Research, 16,(2), 149-168

Fabrigar, L.R., Wegener, D.T., MacCallum, R.C \& Erin J. Strahan, E.J. (1999). Evaluating the use of exploratory factor analysis in psychological research. Psychological Methods, 4(3), 272-299.

George, J. M. (1992). Extrinsic and intrinsic origins of perceived social loafing in organizations. Academy ofManagement Journal, 35: 191-202.

Harkins, S.G \& Szymanski, K (1989). Social Loafing and Group Evaluation Journal of Personality and Social Psychology, 56, (6) ,934-941

Harkins, S.G \& Petty, R.E (1982). Effect of Task difficulty and Task Uniqueness on Social Loafing. Journal of Personality and Social psychology, 43(6), 1214-1229.

Harmaini,. Anastasia, D.F.,Agung, I.M \&. Munthe, R.A (2016). Psikologi Kelompok.:Integrasi Psikologi dan Islam Jakarta: Rajawali Press

Hair, J., Blak, W.C., Babin, B.J., Andersen, R.E., \& Ratham, R.L. (2006). Multi-variate data analysis. Sixth edition. New Jersey: Pearson Prentice Hall.

Hoigaard, R., Safvenbom, R., \& Tønnessen, F. E. (2006). The relationship between

group cohesion, group norms, and perceived social loafing in soccer teams. Small Group Research, 37(3), 217-232.

Hoigaard, R., Tofteland, I., \& Ommundsen, Y. (2006). The effect of team cohesion on social loafing in relay teams. International Journal of Applied Sports Sciences, 18 (1), 59-73.

Jassawalla, A., Sashittal, H \& Malshe, (2009). A Students' Perceptions of Social Loafing: Its Antecedents and Consequences in Undergraduate Business Classroom Teams. Academy of Management Learning \& Education, ,8(1), 42-54.

Karau, J.K \& Williams, K.D.(1993). Social loafing : A Meta-Analytic Review and Theoritical Integration. Journal of Personality and Social Psychology, 65(4) 681-706.

Kusuma, P.J (2015) Hubungan Antara Harga Diri Dengan Pemalasan Sosial. Pada Mahasiswa. Naskah Publikasi diterima dari eprints.ums.ac.id/36113/1/ 
NASKAH\%20PUBLIKASI.pdf, tanggal 2 Juli 2018

Krisnasari, E.S.D \& Purnomo, J.T (2017). Hubungan Kohesivitas Dengan Kemalasan Sosial Pada Mahasiwa Jurnal Psikologi, 13 (1),13-21

Latane, B., Williams, K., \& Harkins, S. (1979). Many hands make light the work: The causes and consequences of social loafing. Journal of Personality and Social Psychology, 37:823-832.

Liden , R.C., Wayne, S.J., Jaworski , R.A., Morgan, S \& Bennett, N.(2004) Social Loafing: A Field Investigation . Journal of Management, 30(2), 285-304

Metiasie , C (2016) Hubungan Motivasi Berprestasi dengan Pemalasan Sosial pada mahasiswa Fakultas Psikologi Universitas Kristen. Diterima dari repository.uksw.edu/ bitstream/123456789/10148/2/ T1_802012042_Full\%20text.pdf. tanggal 2 Juli 2018.

Mulvey, P.W \& Klein, H.J. (1998). The Impact of Perceived Loafing and Collective

Efficacy on Group Goal Processes and Group Performance. Organizational Behavior And Human Decision Processes, 74(1), 62-87.

Murphy, S.M., Wayne, S. J., Liden., R.C.,\& Erdogan, B.(2003); Understanding social loafing: The role of justice perceptions and exchange relationships. Human Relations, 56(1): 61-84

Saputra, N.E Azwar, \& lin Indrawati, I (2016), Kemalasan Sosial, Persepsi Dukungan Organisasi, Komitmen Organisasi, Kepuasan Kerja. JURNAL PSIKOLOGI JAMBI 1, NO 1, : 10-18.

Setyawan, M.S,, Erlyani, N, \& Dewi R, S.(2016). Social Loafing Terhadap Perilaku Prososial Buruh Perusahaan Air Mineral X . Jurnal Ecopsy, 3, (3), 127132.

Stevens, (2009). Applied Multivariate Statistic For The Social Science. Fith edition. New York: Routledge Taylor \& Francis Group New York.

Taylor, S.E., \& Peplau, L.A. \& Sears, D.O. (2009). Psikologi Sosial. Edisi kedua belas. Terj. Jakarta : Kencana Prenada Media Group

Williams, K.D \& Karau, S.J. (1991) Social Loafing and Social Compensation: The Effects

of Expectations of Co-Worker Performance. Journal of Personality and Social
Psychology 61(4), 570-581

Zahra, Y, Eliana, R, Budiman, Z \& Novliadi, F. (2015). Peran Gender dan Social loafing Tendency terhadap Prestasi Akademik dalam Konteks Pembelajaran Kooperatif. Psikologia: Jurnal Pemikiran dan Penelitian Psikologi,10(1) 1-9. 